\title{
Pengaruh Etika Bisnis Terhadap Produktivitas Kerja Karyawan (Studi di KSPPS BTM Sang Surya Pamekasan)
}

\author{
Khairul Jannah, Erwin Yuli Handayani \\ Fakultas Ekonomi dan Bisnis Universitas Trunojoyo Madura
}

\begin{abstract}
ABSTRAK
Istilah etika dalam bahasa Indonesia sebenarnya berasal dari bahasa Yunani: ethos, yang berarti kebiasaan atau watak. Etika juga berasal dari bahasa Perancis: etiquette atau dalam bahasa Indonesia dengan kata etiket yang berarti juga kebiasaan atau cara bergaul, berperilaku yang baik. Etika bisnis adalah aturan-aturan yang menegaskan suatu bisnis boleh bertindak dan tidak boleh bertindak, dimana aturan-aturan tersebut dapat bersumber dari aturan tertulis maupun aturan yang tidak tertulis. Penelitian ini merupakan penelitian penjelasan (explanatory research) yang akan membuktikan hubungan kasual antara variabel bebas (independen variabel), yaitu variabel etika bisnis yang diprosikan denga norma sopan santun, norma hukum, dan norma moral dengan variable terikat (dependen variabel) yaitu prodiktifitas kerja karyawan. Produktifitas adalah perbandingan antara keluaran/output dan masukan/input. Produktifitas kerja merupakan sikap mental, yang selalu mencari perbaikkan terhadap apa yang telah ada. Suatu keyakinan bahwa seseorang dapat melakukan pekerjaan lebih baik hari ini dari pada hari kemarin dan hari esok lebih baik dari hari ini. Secara normatif etika bisnis menciptakan hubungan yang erat antar perusahaan baik pimpinan maupun karyawan membentuk kerjasama yang adil dan sehat serta membangun kerjasama yang erat.
\end{abstract}

Kata Kunci : Etika, Etika Bisnis, Produktivitas Kerja, Karyawan, KSPPS BTM Sang Surya Pamekasan

\section{PENDAHULUAN}

Setiap perusahaan didirikan pasti punya harapan jangka panjang akan berkembang lebih baik dan terlihat produktivtiasnya dalam bidang usaha dari perusahaan tersebut. Perusahaan itu pada dasarnya menginginkantercapainya produktivitas yang tinggi dalam bidangkerjanya. Dengan produktivitas yang tinggi makaperusahaan akan memperoleh keuntungan.Perusahaan adalah urat nadi perekonomianbangsa Indonesia karena dalam mencapaitujuannya mencari laba, harus memenuhi anekaragam kebutuhan masyarakat.Perusahaan yang berjalan baik dibawah naungan organisasi atau milik perorangan merupakan sebuah organisasi yang menggunakan dan mengkoordinir sumber-sumber ekonomi 
untuk memproduksi barang dan jasa di dorong untuk meningkatkan produktivitas usaha sehingga nantinya mampu memaksimalisasikan laba untuk bertahan dalam jangka panjang.Bertahan untuk jangka panjang sebagai bentuk komitmen organisasi untuk publik dalam mempertahankan serta mengembangkan perusahaan sehingga bisa menjawab tantangan persaingan yang semakin komplek dalam dunia usaha.Sumber daya manusia yang militan sangat dibutuhkan dan produktivitas kerja memberikan dampak positif bagi perusahaan untuk melangsungkan serta memelihara eksistensinya untuk jangka panjang.

Produktivitas kerja merupakan motif ekonomi untuk memperoleh hasil maksimal dengan biaya tertentu, dimana dalam pelaksanaannya produktivitas banyak terletak pada faktor sebagai pelaksana kegiatan perusahaan yaitu, para anggota, karyawan atau pekerja. Jadi faktor manusia memegang peranan penting dalam mencapai hasil sesuai dengan tujuan perusahaan, karena betapapun sempurnanya peralatan kerja tanpa adanya tenaga manusia tidak akan berhasil memproduksi barang dan jasa sesuai dengan tujuan yang ingin dicapai (Saksono, 1988)Produktivitas kerja adalah perbandinganantara hasil yang dicapai dengan peran sertatenaga kerja persatuan waktu. (J.Ravianto,1986)

Disetiap perusahaan memerlukan adanya etika bisnis.Etika bisnis itu dibuat oleh organisasi ataupun manajer sebagai sebuah langkah untuk membandingkan apakah yang dilakukan oleh eksekutif perusahaan sesuai dengan rencana yang dibuat dan ditetapkan. Hal ini menunjukkan bahwa etika bisnis akan menjadi pedoman atau acuan ketika mau menjalankan dan mengembangkan bisnis pada perusahaan tersebut.kesesuaian antara rencana dan tindakan akan bisa dilihat pada etika bisnis yang sudah ada.Etika bisnis perusahaan menjadi hal yang sangat penting untuk mengontrol, mengevaluasi serta menjaga eksistensi dan produktivitas perusahaan.

Aktivitas keseharian yang dijalankan harus menyesuaikan dengan etika yang ada di perusahaan. Pengawasan dari seorang manajer akan membantu terhadap pelaksanaan pekerjaan untuk menyesuaikan dengan ketentuan yang ditetapkan. Jika Perusahaan melaksanakan pengawasan secara baik dan benar 
sesuai dengan aturan yang telah dibuat dan ditetapkan serta dilaksanakan sesuai dengan tugas dan wewenang yang telah ditentukan, maka dengan sendirinya disiplin kerja karyawan akan baik. Tjing Bing Tie (1987) mengemukakan Pada umumnya disiplin yang baik terdapat apabila karyawan datang kekantor atau perusahaan dengan teratur dan tepat pada waktunya, apabila mereka berpakaian serba baik pada tepat pekerjaannya, apabila menggunakan bahan-bahan dan perlengkapan dengan hati-hati, apabila mereka menghasilkan jumlah dan kualitet pekerjaan yang memuaskan, dan mengikuti cara kerja yang ditentukan oleh perusahaan dan apabila menyelesaikan dengan semangat yang baik.

Pekerjaan yang dilakukan berdasarkan etika akan sangat berbeda dengan pekerjaan yang dikerjakan berdasarkan kemauan dan cara sendiri-sendiri, orang akan melakukan pengamatan dan penilaian terhadap kinerja perusahaan. Perusahaan-perusahaan yang menjalankan etika bisnis dapat mengurangi biayabiaya terkait dengan hukum dan peraturan, meningkatkan pendapatan dan nilai pemilik melalui loyalitas pelanggan yang sangat kuat dan reputasi yang bagus.Perusahaan yang komit dengan etika dalam berbisnis telah mendapat reputasi baik yang dapat mendongkrak profitabilitas dan pertumbuhan bisnis yang digeluti.Sedangkan Perilaku yang tidak etis mengakibatkan kinerja saham yang lebih rendah daripada yang diharapkan.Studi yang dilakukan oleh Larry (1990) di Amerika menemukan bahwa perusahaan yang komit dengan etika dapat mendongkrak profitabilitas dan pertumbuhan bisnis yang digeluti.

Oleh karena itu manajer harus menerapkan dan menjalankan etika bisnis yang sudah ditetapkan, maka dengan sendirinya disiplin kerja karyawanpun akan baik sehingga karyawan bisa mencapai prestasi kerja yang optimal dalam bentuk produktivitas kerja.Para karyawan cenderung kurang pengawasan dari manajer sehingga sikap disiplin karyawan menjadi kurang. Keadaan ini apabila dibiarkan terus menerus akan mempengaruhi pula tingkat produktivitas kerja karyawan sehingga keuntungan perusahaan tidak sesuai dengan apa yang diharapkan.

Pengaruh etika bisnis terhadap karyawan menjadi sangat penting. Perusahaan perlu melakukan evaluasi kinerja apakah sudah sesuai dengan etika yang dibuat 
sehingga akanmemacu produktivitas kerja karyawan.Karena apabila etika bisnis betul-betul dipakai dan dievaluasi dalam bekerja makasemangat kerja akan timbul dan para karyawanakan bekerja dengan baik, benar, beretika danbertanggung jawab sehingga produktivitas kerjaakan meningkat dengan sendirinya.

Fakta yang ada menunjukkan adanya gejala-gejala yang cenderung terjadi penurunan produktivitas kerja para karyawan. Hal ini disebabkan mereka tidak melakukan dan menggunakan etika bisnis dalam bekerja. Untuk itu dalam meningkatkan produktivitas kerja karyawan manajer harus melakukan dan menerapkan etika bisnissehingga aktivitas kerja yang nyaman dan indah akan hadir dalam diri karyawan. Dengan demikian karyawan akan mengerjakan pekerjaan dengan baik, benar dan beretika sehingga perusahaan bisa merasakan hikmah dan manfaatnya.

Berdasarkan uraian permasalahan diatas, maka dapat dirumuskan permasalahan penelitian ini adalah sebagai berikut :

1. Adakah pengaruh etika bisnis terhadap produktivitas kerja karyawan di KSPPS BTM Sang Surya Pamekasan?

2. Seberapa besar pengaruh etika bisnis terhadap produktivitas kerja karyawandi KSPPS BTM Sang Surya Pamekasan?

Tujuan yang ingin dicapai adalah sebagai berikut :

1. Untuk mengetahui ada atau tidaknya pengaruh etika bisnis terhadap produktivitas kerja karyawan di KSPPS BTM Sang Surya Pamekasan.

2. Untuk mengetahui seberapa besar pengaruh etikabisnis terhadap produktivitas kerja karyawan di KSPPS BTM Sang Surya Pamekasan.

\section{METODE}

Penelitian ini merupakan penelitian penjelasan (explanatory research) yang akan

membuktikan hubungan kasual antara variabel bebas (independen variabel), yaitu variabel etika bisnis yang diprosikan denga norma sopan santun, norma hukum, 
dan norma moral dengan variable terikat (dependen variabel) yaitu prodiktifitas kerja karyawan.. jenis penelitian ini dipilih agar dapat dibangun suatu hasil analisis yang dapat berfungsi untuk menjelaskan, meramalkan, dan mengontrol suatu gejala atau hubungan antara variabel bebas dengan variabel terikat (Arikunto, 2002).

Populasi dalam penelitian ini adalah Karyawan sebanyak 15 orang diKSPPS BTM Sang Surya Pamekasan. lokasi penelitian ini dilakukan pada KSPPS BTM Sang Surya Pamekasan dengan alasan pertama karena itu adalah salah satunya koperasi keuangan yang dimiliki oleh muhamdiyah pamkesan, kedua karena amal usaha tersebut di bawah naungan mejelis ekonomi dan kewirausahan ketiga

Penelitian ini menarik sampel dengan menggunakan metode atau tehnik simple random sampling, dimana jumlah sampel ditentukan dengan menggunakanrumus dari taro

yamane dalam sugiono (2005) yaitu $\mathrm{n}=\mathrm{N}:((\mathrm{NXd} 2)+1)$ dimana $\mathrm{n}$ adalah jumlah sampel, $\mathrm{N}$ adalah jumlah populasi, dan $\mathrm{d} 2$ adalah tingkat presisi atau akurasi yang ditetapkan $(=10 \%)$, sehingga besarnya sampel adalah sebanyak 47 pekerja koperasi.

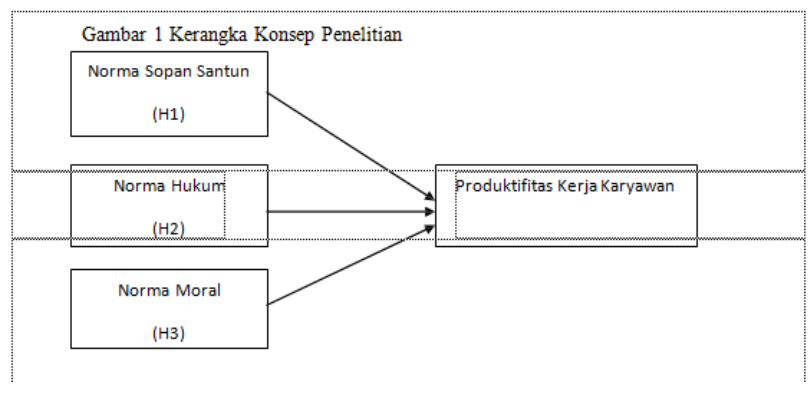

\section{DEFINISI OPERASIONAL DAN PENGUKURAN VARIABEL}

Etika Bisnis (X) diartikan sebagai Etika bisnis adalah aturan-aturan yang menegaskan

suatu bisnis boleh bertindak dan tidak boleh bertindak, dimana aturan-aturan tersebut dapat bersumber dari aturan tertulis maupun aturan yang tidak tertulis. Dan jika suatu bisnis melanggar aturan tersebut maka sanksi akan diterima. Dimana sangsi tersebut dapat berbentuk langsung maupun tidak langsung. (Irham Fahmi, 2015:3). Dimensi Etika Bisnis meliputi :

a. Dimensi Norma sopan santun (X1), di sebut juga norma etiket, adalah norma 
yang mengatur pola perilakuu dan sikap lahirlah manusia. Misalnya menyangkut sikap dan perilaku seperti saat kita bertamu, makan dan minum, cara duduk dan berpakaian, dan seterusnya. norma ini lebih menyangkut tata cara lahirla dalam pergaulan sehari - hari.

b. Dimensi Norma hukum (X2) adalah norma yang di tuntut keberlakuannya secara tegas oleh masyarakat karena di anggap perlu dan niscaya demi keselamatan dan kesejahteraan manusia dalam kehidupan bermasyarakat. Norma ini mencerminkan harapan, keinginan dan keyakinan seluruh anggota masyarakat tersebut dan kesejahteraan bermasyrakat yang baik dan bagaimana masyrakat tersebut harus di atur secara baik.

c. Dimensi Norma moral (X3), yaitu aturan mengenai sikap dan perilaku manusia sebagai manusia. Norma ini menyangkut aturan tentang baik - buruknya, adil tidaknya tindakan dan perilaku manusia sejauh dilihat sebagai manusia. Norma moral dipakai sebagai indikator oleh masyarakat untuk menentukan baik buruknya tindakan manusia kepada pihak lain dengan fungsi dan jabatannya di masyrakat.

Produktifitas kerja karyawan (Y) adalah perbandingan antara keluaran/output dan

masukan/input. Produktifitas kerja merupakan sikap mental, yang selalu mencari perbaikkan terhadap apa yang telah ada. Suatu keyakinan bahwa seseorang dapat melakukan pekerjaan lebih baik hari ini dari pada hari kemarin dan hari esok lebih baik dari hari ini (Tohardi,

2002). Produktifitas diukur dengan :

a. Target, Target merupakan indikator terhadap pemenuhan jumlah barang, pekerjaan, atau jumlah uang yang dihasilkan.

b. Kualitas, Kualitas adalah elemen penting, karena kualitas yang dihasilkan menjadi kekuatan dalam mempertahankan loyalitas pelanggan.

c. Waktu Penyelesaian,Penyelesaian yang tepat waktu membuat kepastian distribusi dan penyerahan pekerjaan menjadi pasti. Ini adalah modal untuk membuat kepercayaan pelanggan

d. Taat asas, Tidak saja hanya memenuhi target, kualitas dan tepat waktu tapi juga harus dilakukan dengan cara yang benar, transparan dan dapat 
dipertanggungjawabkan.

Data yang di ambil dalam penelitian ini adalah berupa data primer, sedangkan metode pengumpulan data dilakukan dengan kuesioner yang diberikan kepada responden secara langsung (Sugiyono,2005). Tehnik analisis data merupakan alat yang dipergunakan dalam memecakan masalah. Penelitian ini menggunakan metode regresi linear berganda dan pengujian hipotesis dilakukan dengan menggunakan uji t, uji f, dan uji R2. Analisis regresi dugunakan untuk mengetahui bagaimana kuatnya pengaruh beberapa variabel independent terhadap variabel dependen, yaitu etika bisnis terhadap produktifitas kerja karyawan di koperasi KSPPS BTM Sang Surya Pamekasan.

\section{HASIL DAN PEMBAHASAN}

Uji Validitas dilakukan untuk melihat valid tidaknya masing - masing instrumen yang

digunakan dalam variabel penelitian. Sesuai dengan hasil analisis data primer, maka masing - masing instrumenyang digunakan dalam penelitian memiliki hasil uji yang menunjukkan bahwa sig correlation < @ (5\%) dan $\mathrm{t}$ hitung > t tabel $(0,279)$. Hasil analisis semua t hitung $>\mathrm{t}$ digunakan dalam instrumen penelitian adalah valid (Ghozali, 2005)

Uji realibitas instrumen penelitian mempertimbangkan besarnya koefisien realibilitas. Sesuai dengan hasil analisis data primer, maka masing - masing instrumen yang digunakan dalam penelitian memiliki hasil uji yang menunjukkan bahwa angka cronbach alpha diatas

0,6 (Ghozali, 2005), artinya dari Uji realibilitas dapat dikatakan bahwa seluruh variabel yang digunakan dalam penelitian ini adalah reliabel.

\section{Hasil Uji Asumsi Klasik}

Tujuan penggunaan uji asumsi klasik adalah agar diperoleh estimator tidak bias dari

regresi dengan kuadrat terkecil biasa. Model regresi yang baik adalah jika tidak terjadi hubungan antar variabel independen. Kriteria pengukurannya adalah jika nilai toleransi $<1$ berarti tidak ada toleransi anrtar variabel independen 
dan jika VIF tidak melebihi 10, maka model dinyatakan tidak terkena persoalan multikoliniear (ghozali, 2005). Ihtisar uji multikoliniear sebagaimana output SPSS dapat dilihat pada tabel 1. Hasil uji multikolinear menunjukkan tiga variabel bebas tidak mengalami multikolineariltas.

Tabel 1. Interpretasi uji multikolinearlitas

\begin{tabular}{|l|l|l|l|l|}
\hline NO & Variabel & Tolerance & VIF & Keputusan \\
\hline 1 & Norma Sopan Santun (X1) & 0,802 & 1,248 & Tidak Terjadi multiko \\
\hline 2 & Norma Hukum (X2) & 0,722 & 1,385 & Tidak Terjadi multiko \\
\hline 3 & Norma Moral (X3) & 0,869 & 2,151 & Tidak Terjadi multiko \\
\hline
\end{tabular}

Uji heteroskedasitas dilakukan dengan menggunakan grafik scatter plot, jika titik - titik menyebar secara acak dan tidak membentuk suatu pola tertentu yang jelas, serta tersebar baik di atas maupun dibawa angka 0 pada sumbu $\mathrm{y}$, hal ini berarti tidak terjadi heteriskedisitas atau data homogen (Ghozali,2005), gambar scatter plot uji heteroskedasitas dapat dilhat pada gambar 2.
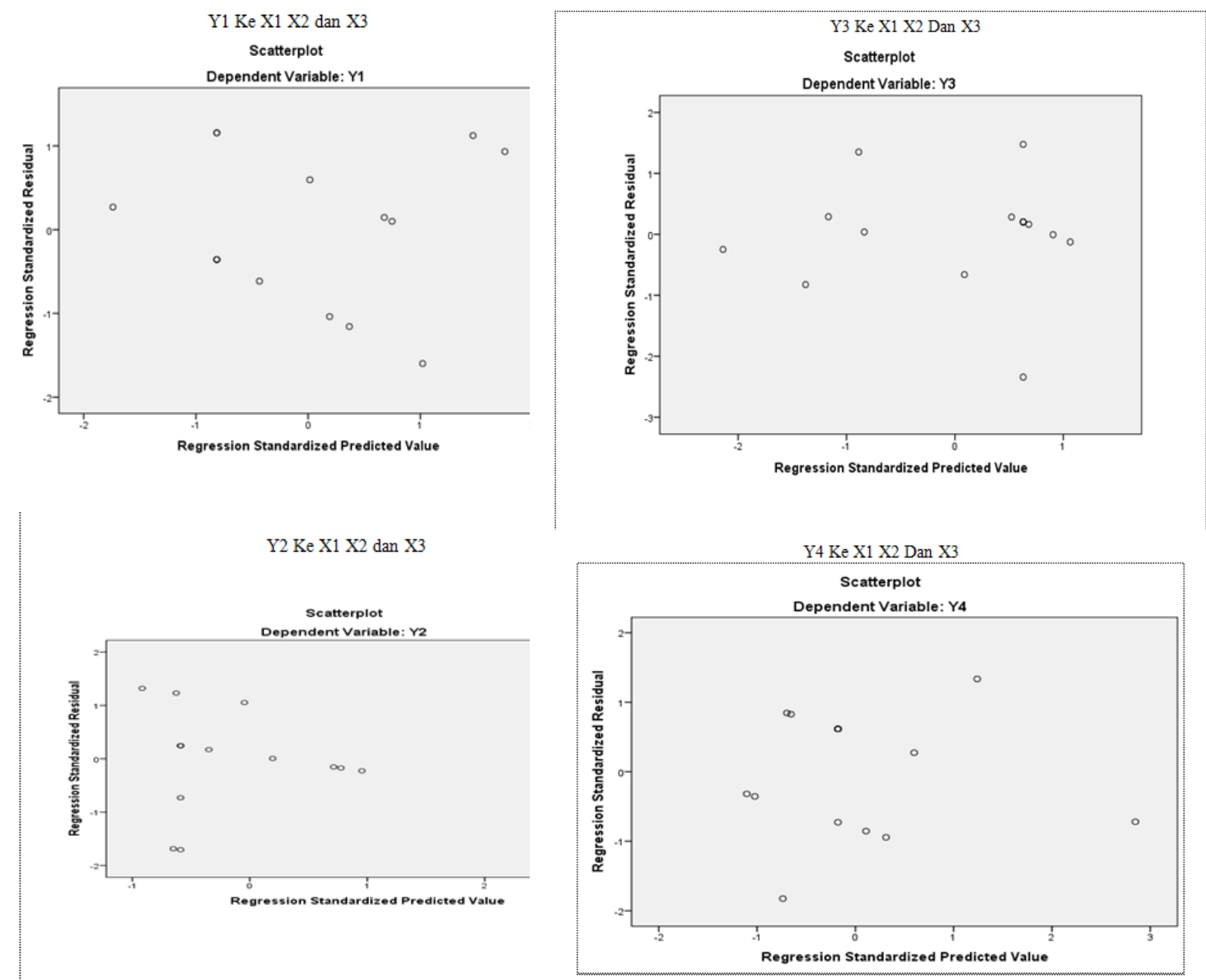

Pada grafik scatter plot hasil output SPSS terlihat titik-titik menyebar secara acak dan tidak membentuk suatu pola tertentu yang jelas, serta tersebar baik di atas maupun di bawah 
angka 0 pada sumbu $\mathrm{Y}$, hal ini berarti data telah memenuhi asumsi homogenitas atau tidak terjadi heteroskedastisitas.

Model regresi yang baik adalah jika semua variabel berdistribusi normal. Jika data menyebar di sekitar garis diagonal dan mengikuti arah garis diagonal, maka model regresi memenuhi asumsi normalitas (Ghozali, 2005).

Pengujian statistik dengan alat analisis regresi linier berganda dimaksudkan untuk mengetahui pengaruh norma sopan santun (X1), norma hukum (X2), dan norma moral(X3), terhadap Produktifitas Kerja Karyawan pada KSPPS BTM Sang Surya Pamekasan. Ikhtisar output uji regresi liniear berganda dapat dilihat pada Tabel 2.

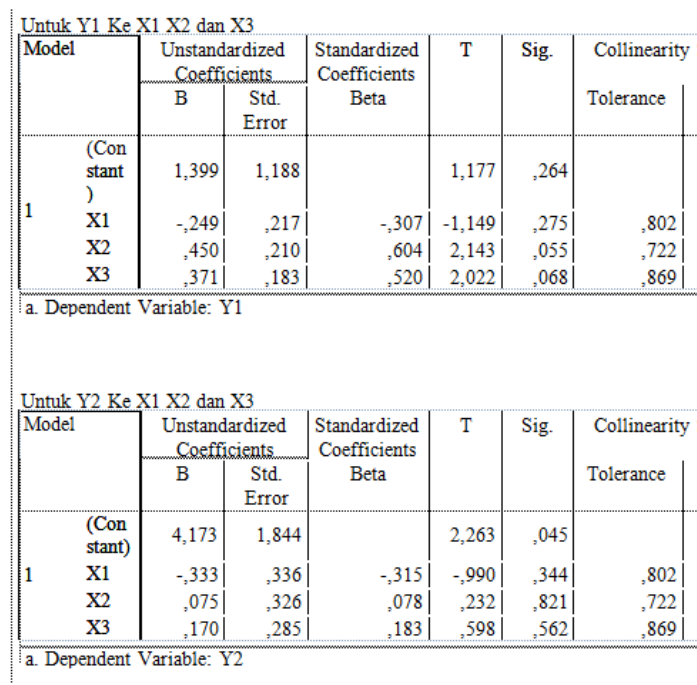

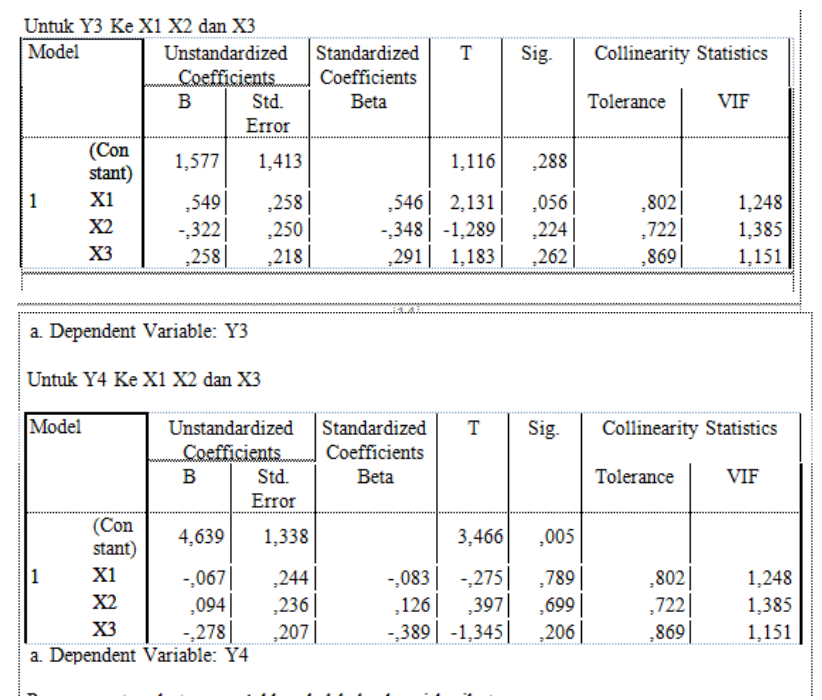

Persamaan tersebut menunjukkan hal-hal sebagai berikut:

(1) Nilai koefisien konstanta adalah sebesar 1,339. Hal ini berarti bahwa apabila nilai koefisien norma sopan santun (X1), norma hukum (X2), dan norma moral (X3) sebesar 0 (nol), maka produktifitas kerja karyawan akan naik sebesar 1,339 untuk Y1 ke X1 X2 dan X3

(2) Nilai koefisien konstanta adalah sebesar 4,173. Hal ini berarti bahwa apabila nilai koefisien norma sopan santun (X1), norma hukum (X2), dan norma moral (X3) sebesar 0 (nol), maka produktifitas kerja karyawan akan naik sebesar 4,173 untuk Y2 ke X1 X2 dan X3

(3) Nilai koefisien konstanta adalah sebesar 1,577. Hal ini berarti bahwa apabila nilai koefisien norma sopan santun (X1), norma hukum (X2), dan norma moral (X3) sebesar 0 (nol), maka produktifitas kerja karyawan akan naik sebesar 1,577 untuk Y3 ke X1 X2 dan X3 
(4) Nilai koefisien konstanta adalah sebesar 4,639. Hal ini berarti bahwa apabila nilai koefisien norma sopan santun (X1), norma hukum (X2),dan norma moral (X3) sebesar 0 (nol), maka produktifitas kerja karyawan akan naik sebesar 4,639 untuk Y4 ke X1 X2 dan X3

(5) Variabel norma sopan santun (X1) untuk Y1 ke X1 X2 dan X3 memiliki nilai koefisien sebesar ,249. Hal ini menunjukkan bahwa setiap satuan variabel norma sopan santun akan berpengaruh terhadap produktifitas kerja karyawan sebesar ,249 apabila variabel lainnya tetap.

(6) Variabel norma hukum (X2) untuk Y2 ke X1 X2 dan X3 memiliki nilai koefisien sebesar ,333. Hal ini menunjukkan bahwa setiap satuan variabel norma hukum akan berpengaruh terhadap produktifitas kerja karyawan sebesar ,333 apabila variabel lainnya tetap.

(7) Variabel norma moral (X3) untuk Y3 ke X1 X2 dan X3 memiliki nilai koefisien sebesar ,549. Hal ini menunjukkan bahwa setiap satuan variabel norma sopan santun akan berpengaruh terhadap produktifitas kerja karyawan sebesar ,549 apabila variabel lainnya tetap.

Uji t digunakan untuk menguji kebenaran hipo- tesis penelitian. Pengujian dilakukan dengan alat penguji signifikansi t-test. Kriteria yang digunakan untuk menyatakan apakah koefisien korelasi parsial yang diperoleh signifikan atau tidak signifikan adalah milai koefisien t. Uji t merupakan uji signifikansi untuk mengukur keberartian koefisien regresi

variabel independen satu per satu. Nilai koefisien $t$ harus dibandingkan dengan harga ttabel untuk alpha yang ditetapkan dengan $\mathrm{dk}$ yang sesuai, untuk $\mathrm{dk}$ $(\mathrm{n}-\mathrm{k}-1)=\mathrm{dk}(50-4-1)=\mathrm{dk}(45)$ dengan alpha 5\% adalah sebesar 1,679. Kriteria yang digunakan, yaitu menolak H0 dan menerima Ha apabila thitung > ttabel serta menerima H0 dan menolak Ha apabila thitung < ttabel, atau melihat dari harga probabilitas hitung dibandingkan dengan level of significance ( $\square$ ) yang sudah ditetapkan yaitu $(0,05)$. Kriteria yang diguna - kan, yaitu menolak H0 dan menerima Ha apabila probabilitas hitung < level of significance ( $\square$ ) serta 
menerima $\mathrm{HO}$ dan menolak Ha apabila probabilitas hitung > level of significance $(\square)$.

1) Uji signifikan t-test antara norma sopan santun (X1) terhadap produktivitas kerja karyawan (Y). Dari hasil analisis diperoleh nilai thitung norma sopan santun (X1) sebesar-1,149 pada tingkat probabilitas -1,149. Hasil pengujian menunjukkan bahwa nilai probabilitas hitung $-1,149<0,05$ atau probabilitas hitung $<$ level of significance $(\square)$, sehingga H0 ditolak. Hal ini berarti bahwa norma sopan santun (X1) ber- pengaruh positif dan signifikan terhadap produktifitas kerja karyawan koperasi KSPPS BTM Sang Surya Pamekasan(Y) diterima.

2) Uji signifikan t-test antara norma hukum (X2) terhadap produktifitas kerja karyawan (Y). Dari hasil analisis diperoleh thitung norma hukum (X2) sebesar 2,143 pada tingkat probabilitas 2,143. Hasil pengujian menunjukkan bahwa nilai probabilitas hitung 2,143>0,05 atau probabilitas hitung > level of significance ( $\square$ ), sehingga H0 diterima. Hal ini berarti bahwa norma hukum (X2) tidak berpengaruh negatif dan signifikan terhadap produktifitas kerja karyawan koperasi KSPPS BTM Sang Surya Pamekasan(Y) diterima.

3) Uji signifikan t-test antara norma moral (X3) terhadap produktifitas kerja kar yawan(Y). Dari hasil analisis diperoleh thitung norma moral (X3) sebesar 2,022 pada tingkat probabilitas 2,022. Hasil pengujian menunjukkan bahwa nilai prbabi- litas hitung 2,022>0,05 atau probabilitas hitung > level of significance $(\square)$, sehingga H0 diterima. Hal ini berarti bahwa norma moral (X3) tidak berpengaruh positif dan signifikan terhadap produktifitas kerja karyawan koperasi KSPPS BTM Sang Surya Pamekasan(Y) diterima.

Uji F digunakan untuk mengetahui pengaruh secara simultan variabel norma sopan santun (X1), norma hukum (X2), dan norma moral (X3), terhadap produktifitas kerja karyawan (Y). Kriteria pengujian menyatakan jika probabilitas hitung < level of significance $(\square)$, maka $\mathrm{H} 0$ ditolak atau ada pengaruh positif dan signifikan secara simultan etika bisnis yang diproksikan dengan norma sopan 
santun (X1), norma hukum (X2), dan norma moral (X3), , terhadap produktifitas (Y). Dari hasil pengujian diperoleh nilai probabilitas hitung $0,000<0,05$ atau probabilitas hitung $<$ level of significance $(\square)$ atau H0 ditolak. Hal ini berarti bahwa variabel etika bisnis yang diproksikan dengan norma sopan santun (X1), norma hukum (X2), dan norma moral (X3), secara simultan berpengaruh positif dan signifikan terhadap produktifitas (Y). Berdasarkan analisis F- test tersebut, maka hipotesis penelitian yang berbunyi terdapat pengaruh signifikan dan positif secara simul- tan variabel etika bisnis yang diproksikan dengan norma sopan santun (X1), norma hukum (X2), dan norma moral (X3), terhadap produktifitas kerja karyawan (Y) dapat diterima atau teruji kebenarannya.

Berdasarkan perbandingan standarized beta pada variabel bebas diperoleh nilai standarized beta dari norma sopan santun (X1) adalah ,307, (X2) norma hukum adalah -

,604, norma moral (X3) adalah ,520 maka dapat dinyatakan bahwa variabel yang memiliki pengaruh paling dominanadalah norma moral (X2). Hal ini disebabkan norma moral (X2) memiliki nilai standarized beta lebih tinggi dibandingkan variabel lainnya.

Brow et al. (2010) mengatakan bahwa etika bisnis memberikan sumbangan yang cukup besar dalam membentuk perilaku etis dalam berbisnis. Perilaku etis ini tidak terlepas dari dua faktor penting yang mempengaruhinya, yaitu: pertama, faktor individual (seseorang), misal, masa kerja, usia, psikis, fisik, jenis kelamin dan motivasi berperilaku. Kedua, situasional atau lingkungan luar, misalnya suasana kerja, lingkungan kerja, dan lain sebagainya. Keinginan berperilaku etis merupakan salah satu keinginan manusia dalam berkehidupan. Keinginan-keinginan tersebut tidak dapat dilepaskan dari sifat manusia yang tidak pernah puas dan selalu ingin mendapatkan yang lebih dari yang telah didapatnya. Lingkungan juga ikut membentuk manusia dengan adanya interaksi dan internalisasi nilai - nilai. Dengan interaksi dan internalisasi nilai-nilai tersebut, manusia dapat berubah perilakunya yang akan berpengaruh pada aktivitas kerjanya. 
Pengaruh Norma Sopan Santun Terhadap Produktifitas Kerja karyawan

Norma sopan santun adalah peraturan hidup yang timbul dari hasil pergaulan

sekelompok itu. Norma kesopanan bersifat relatif artinya apa yang di anggap sebagai norma ksepoanan berbeda beda di berbagai tempat, lingkungan atau waktu. Contoh - contoh norma sopan santun ialah :

1) Menghormati orang yang lebih tua

2) Menerima sesuatu selalu dengan tangan kanan

3) Tidak berkata - kata kotor kasar dan takabur

4) Tidak meluda di sembarang tempat

5) Tidak menyelah pembibicaraan

Norma sopan santun sangat penting untuk diterapkan, terutama di dalam bermasyrakat, karena norma ini sangat erat kaitannya terhadap masyrakat. Sekali saja ada pelanggaran terhadap norma kesopanan, pelanggar akan mendapat sanksi dari masyrakat, semisal cemoohan. Kesopanan merupak tuntunan dalam hidup bersama. Ada norma yang harus dipenuhi supaya di terimah secara sosial.

Sedangkan perilaku tidak sopan atau tidak tau sopan santun istilanya disebut kurang ajar. Sanksi bagi pelanggar norma kesopanan adalah tidak tegas, tetapi dapat di berikan oleh masyrakat, yang berupa cemoohan celaan, hinaan, atau dikucilkan dan di asingkan dari prrgaulan serta dipermalukan.

Pengaruh Norma Hukum Terhadap Produktifitas Kerja Karyawan

Norma hukum hampir sama dengan norma moral hanya lingkupnya lebih besar

misalnya suatu negara, bersifat tertulis yang dilaksanakan oleh suatu lembaga dan mengikat dari sisi sangsinya karena berisi benara atau salah. Contohnya adalah hukum perdata dan hukum pidana.

Pengaruh Norma Moral Terhadap Produktifitas Kerja Karyawan

Norma moral adalah standar yang menjadi tolak ukr suatu nilai moral ketika 
terjadi

benturan, yang dibuat oleh tokok masyrakat setempat sehingga mempunyai dampak sanksi - sanksi sosial meskipun tidak tertulis. Contoh berdasarkan daerah saya adalah seseorang menggunakan kata - kata kasar di daerah tersebut, dimana kata - kata kasar ini hanya berlaku di daerah tertentu dan terkadang tidak mempunyai arti sehingga dampaknya karena berbenturan dengan sistem di masyrakat, orang tersebut mendapat julukan, misalnya orang kasar. Contoh lain tidak merokok ketika umurnya belum dewasa.

\section{KESIMPULAN DAN SARAN}

Berdasarkan pembahasan pada bab-bab sebelum- nya, selanjutnya dapat dirumuskan

beberapa kesim- pulan sebagai berikut:

1. Etika bisnis adalah aturan-aturan yang menegaskan suatu bisnis boleh bertindak dan tidak boleh bertindak, dimana aturan-aturan tersebut dapat bersumber dari aturan tertulis maupun aturan yang tidak tertulis. Dan jika suatu bisnis melanggar aturan tersebut maka sanksi akan diterima. Dimana sangsi tersebut dapat berbentuk langsung maupun tidak langsung.

2. Koperasi KSPPS BTM Sang Surya Pamekasan adalah salah satunya koperasi keuangan yang dimiliki oleh muhamadiyah pamekasan dan amal usaha tersebut di bawah naungan mejelis ekonomi dan kewirausahan

3. Norma Sopan Santun, ketika karyawan memiliki sopan dan santun dalam menjalankan bisnisnya maka berdampak pada karakter karyawan. Karakter karyawan akan mulai tumbuh dan akan berpengaruh terhadap produktifitas kerjanya.

4. Norma Hukum Ketika norma hukum di terapkan dan dijalankan maka karyawan tidak semudah melakukan pelanggaran karena akan berdampak sangsi yang akan diterima dan bisa juga berhadapan dengan hukum

5. Norma Moral, moral seseorang sangat berpengaruh dalam kinerja , jika 
memiliki watak yang keras dan sulit di atur maka moral seseorang tersebut tidakla baik, tidak mudah mengubah moral seseorang karna moral juga hubungannya sama watak atau perwatakan.

6. Produktifitas, seseorang karyawan dapat dikatan produktifitas ketika ia displin dalam mengemban tugas yang menjadi tanggung jawabnya dalam mengerjakan dan menyelesaikan pekerjaannya.

Berdasarkan hasil penelitian, pembahasan, dan keterbatasan penelitian, maka dapat dikemukakan saran-saran sebagai berikut:

1. Secara normatif etika bisnis menciptakan hubungan yang erat antar perusahaan baik pimpinan maupun karyawan membentuk kerjasama yang adil dan sehat serta membangun kerjasama yang erat.

2. Bagi Pimpinan haruslah rama, sopan,santun, beretika, berahlak dan beromoral agar dapat menjadi panutan karyawan sehingga juda dapa meningkatkan produktivitas kerja karyawan.

3. Bagi peneliti lain yang akan meneliti tentang etika bisnis terhadap produktifitas kerja karyawan, ruang ingkup penelitian hendaknya diperluas sehingga hasil penelitian dapat digeneralisasi. Perlu mempertimbangkan faktor-faktor lain baik eksternal maupun internal sebagai faktor yang ikut menentukan perilaku etis dalam berbisnis.

\section{DAFTAR PUSTAKA}

Arijanto Agus, 2011, Etika Bisnis bagi Pelaku Bisnis (Cara cerdas dalam memahami konsep dan faktor-faktor etika bisnis dengan beberapa contoh praktis).Jakarta:Rajawali Pers

Fahmi Irham, 2015, Etika Bisnis (Teori, Kasus, dan Solusi). Bandung:Alfabeta.

Hartman Laura P, Desjardins Joe, 2008, Etika Bisnis (Pengambilan keputusan untuk integritas dan tanggung jawab sosial). Jakarta:Erlangga.

Akhyadi Sadikin, Kaswan, 2015, PengembanganSumberDayaManusia (Dari 
Konsepsi, Paradigma, danFungsiSampaiAplikasi). Bandung:Alfabeta.

Edison Emron, dkk, 2016, Manajemen Sumber Daya Manusia (Strategi dan perubahan dalam rangka meningkatkan kinerja pegawai dan organisasi). Bandung: Alfabeta

Marwanto. 2010. Pengaruh pengawasan kerja dan disiplin kerja terhadap produktivitas kerja karyawan bagian produksi perusahaan "Manufaktur": Jurnal Jurusan Akutansi Politeknik Negeri Samarinda.vol 6, no 1, p. 13801381.

Ahmad Roziq. 2010. Pengaruh Etika Bisnis Islami terhadap kinerja pembiayaan mudharabah melalui informasi asimetri pada Bank Syariah di Jawa Timur: Jurnal fakultas ekonomi universitas jember.vol IX, no 1, p. 5758.

Fauzan. 2013. Pengaruh religiusitas terhadap etika berbisnis: Jurnal fakultas ekonomi universitas kanjuruhan malang.vol 15, no 1, p. 54-55

Bambang Widjanarko. 2016. Pengaruh motivasi instrinsik, pengawasan dan budaya kerja terhadap produktivitas kerja karyawan PTPN IV Dolok Ilir: Jurnal STIM Sukma Medan.vol 2, no 1, p. 7.

Desi Rahmawati. 2013. Pengaruh motivasi terhadap produktivitas kerja karyawan PR Fajar

Berlian Tulungagung: Jurnal fakultas ekonomi universitas tulungagung.vol 1, no $1, \mathrm{p}$. 